\title{
当科における縦隔気管孔症例の検討
}

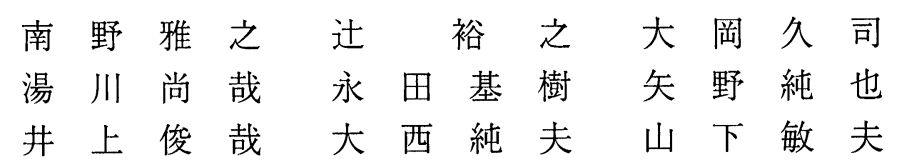

要旨: 縦隔気管孔は気管皮膚縫合部と縦隔を隔離する組織がそしいため, 縫合部に感染が生じた場合, 感染が縦隔内に容易に波及する。また, 縦隔洞炎や気管壊死により腕頭動脈の破裂の危険性がある。著 者らはこの術後合併症を回避するため, 大胸筋弁を用いて縦隔気管孔周囲を被覆し縦隔内の大血管から 縦隔気管孔を隔離した術式を施行してきた。今回, 平成 10 年から 15 年の間に当科において縦隔気管孔 を作製した 6 症例について検討した。全例において気管壊死や気管腕頭動脈瘦，縦隔洞炎などの致命的 な合併症は認められなかった。 キーワード : 縦隔, 気管孔, 大胸筋弁

\section{Summary Evaluation of patients with a mediastinal tracheostoma at our department:}

Masayuki Minamino, Hiroyuki Tsuji, Hisashi Ooka, Hisaya Yukawa, Motoki Nagata, Jyunya Yano, Toshiya Inoue, Sumio Oonishi, and Toshio Yamashita. Department of Otolaryngology, Kansai Medical University

Mediastinal tracheostomas have poor tissue separating the tracheal skin suturing area and the mediastinum and therefore, infection occurring in the suture area readily extends to the mediastinum. In addition, there is the risk of rupture of the brachiocephalic artery due to mediastinitis or tracheal necrosis. To avoid this postoperative complication, we have performed an operative technique in which the mediastinal tracheostoma and the surrounding area are covered using a pectoralis major muscle flap for separation of the tracheostoma from mediastinal major blood vessels. In this study, we evaluated 6 patients who underwent mediastinal tracheostomy at our department between 1998 and 2003. No fatal complications such as tracheal necrosis, fistulation between the trachea and brachiocephalic artery, or mediastinitis were observed in any patient.

Key words : mediastinum, tracheostoma, pectoralis major muscle flap

はじめに

広範囲な気管切除を必要とする症例では，胸骨 や胁骨を一部除去してから, 縦隔を経由して気管 断端を引き出し，前胸壁の皮膚に縫合する縦隔気

関西医科大学耳鼻咽喉科
管孔を作製する。この時，さらに気管に緊張がか からないように，気管を腕頭動脈の右側にくぐら せた Grillo1)の方法が汎用されている。しかしな がら, 縦隔気管孔症例においては, 気管壊死をふ くめた気管孔周囲の感染が縦隔内に波及すること による縦隔洞炎や大血管の破綻などの致命的な合 


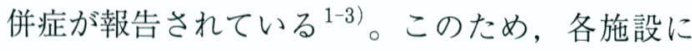
おいて広背筋・前腕皮弁・有茥大網などで気管周 囲を被覆する工夫がなされてきた ${ }^{3-6)}$ 。今回，当 科において縦隔気管孔を作製した症例について検 討し，その術式の工夫や成績を報告する。

\section{1. 対 象}

平成 10 年から 15 年の間に, 当科において縦隔 気管孔造設術を施行した 6 症例である。6 症例の 内訳は, 喉頭癌の気管孔再発が 2 例, 喉頭癌術後 気管壊死 1 例, 甲状腺扁平上皮癌・未分化癌の気 管浸潤例各 1 例, 甲状腺癌縦隔郭清術後における 永久気管孔開大時の腕頭動脈損傷 1 例である。

\section{2. 縦隔気管孔の手術方法}

喉頭癌気管孔再発症例における, 縦隔気管孔造 設時の術中所見を示す（図 1)。胸骨柄と右鎖骨骨 頭, 第 1 ・第 2 肋骨付着部を切除するが, 術後奇 異呼吸を予防するため可能な限り左側の胸鎖関節 は保存している。気管を 8 リング切除後，気管に 緊張を加えないように, 腕頭動脈の右側でくぐら せた Grilloの術式を行い（図 1a），気管孔から大 血管への感染を予防するために，大胸筋皮弁を気 管と腕頭動脈の間に挟み込み, 気管孔の $11^{\circ} \sim 6^{\circ}$ の方向に縫着して気管孔周囲への緊張を防ぎなが
ら形成をした（図 1b）。6 症例中 5 例において残 存気管を腕頭動脈の深部にくぐらせた Grilloの方 法に大胸筋皮弁を用いて縫着し, 残り 1 例は残存 気管をそのまま前方に引き出し大胸筋弁を気管と 大血管の間に挟み込み，前胸部の皮膚をそのまま 気管断端に縫合した縦隔気管孔造設術を施行した。

\section{3. 術後経過}

6 例中 3 例は死亡しており，その内訳は，喉頭 癌頸部皮膚再発例，術中迅速病理検査で判明した 甲状腺未分化癌の食道再発例, 喉頭全摘後の気管 壊死症例において術前からの頸部感染が術後も制 御できず右頸動脈分岐部周囲から出血死した症例 であった。しかしながら，全例において縦隔気管 孔造設術の術後に関連した気管壊死や気管腕頭動 脈瘦, 縦隔洞炎などの致命的な合併症は認めなかっ た。

\section{考察}

縦隔気管孔造設術については，本邦でも 1977 年に村上らがその基本的術式について詳細に述べ ている ${ }^{7)}$ 。そして, 縦隔気管孔の重篤な合併症と して, 皮虐との過緊張により気管壊死を生じる事, 気管周囲および縦隔に死腔を形成しやすいために, この部位の感染に伴って気管腕頭動脈瘻や縦隔洞

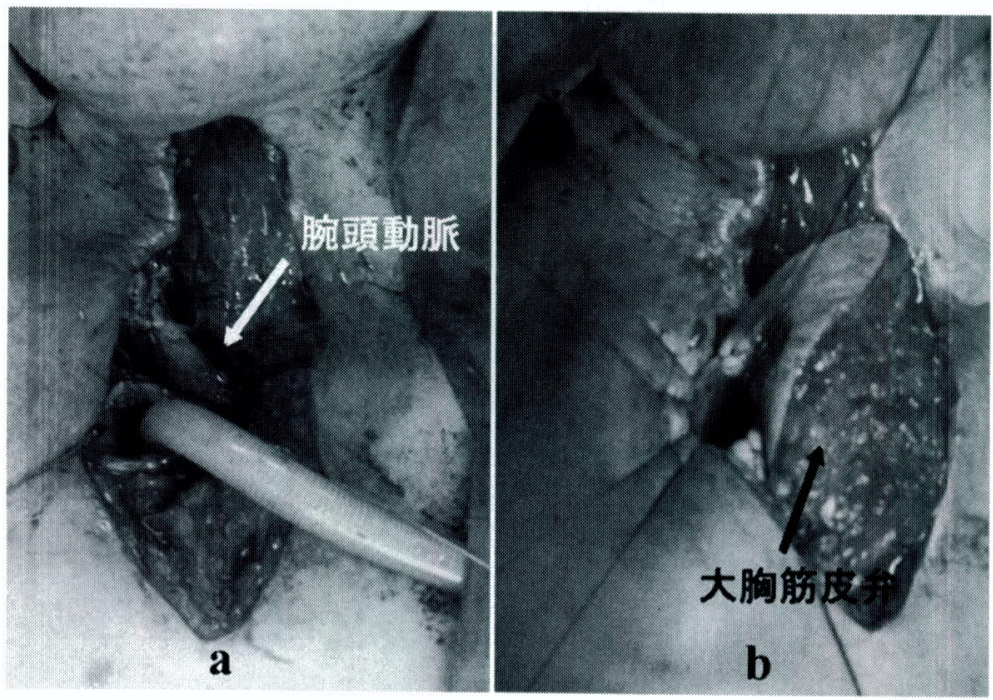

図 1 縦隔気管孔造設時の術中所見 
炎を生じる事が報告されている。そこで，当科に おける縦隔気管孔造設時の対策として，(1)気管の 血流を保つため気管鞘を傷つけない，(2)永久気管 孔作製時に気管に緊張をくわえないように，気管 断端をあまり引き出さず前胸壁の皮膚を充分に undermining し，場合により回転皮弁を用いて皮 虐を縦隔内に落とし込んで縫合する，(3)腕頭動脈 の保護として大胸筋を気管と腕頭動脈の間に挟み こんでいるが，これは同時に気管への二次血行も 期待している，(4)特に Grillo 手術の際には，気管 への緊張の緩和と死腔の充填および腕頭動脈の保 護のために，大胸筋皮弁を気管孔の $11^{\circ} \sim 6^{\circ}$ の方 向に縫着する術式をとっている。これまで，縦隔 気管孔の重篤な合併症の予防として，広背筋・ $\mathrm{DP}$ ・前腕皮弁などで気管周囲を被覆している報 告があるが，著者らが用いた大胸筋皮弁で充分に 大動脈周囲の死腔を充填することができ，前胸壁 に過度の緊張がかかることなく，気管孔周囲に皮 膚を落とし込んで縫合することができた。しかも， 大胸筋皮弁は挙上が手技的に容易であり，同一術 野で操作が可能である点で有用であると思われた。 術後の創部感染は, 縦隔洞炎を引き起こし, 大血 管の破裂が必発とされているだけに，死腔を残さ ないこと，気管に緊張を加えないことに最大の注 意を払い手術を行う必要がある。術後の管理につ いて，永久気管孔であるため長期的にカニューレ を挿入しておく必要はないが，大胸筋皮弁を押し 込んでいるために術後の腫脹により気管孔入口部 が狭窄しないように，また押し込んだ位置で固定 するために経過を診ながら約1週間入れておく。 気管の圧迫疎血壊死を起こさないようカニューレ のカフ圧は低くしておく必要がある。
まとめ

1. 過去 5 年間に 6 例の縦隔気管孔症例を経験 した。

2. 6 例中 3 例が現在生存しており，3 例が原 疾患の再発等で死亡した。

3. 縦隔気管孔造設術の留意点について検討し た。

4. 今回の縦隔気管孔造設術 6 症例全例におい て気管壊死や気管腕頭動脈瘦, 縦隔洞炎などの致 命的な合併症は認められなかった。

この論文の要旨は第 14 回日本頭頸部外科学会総会 (2004 年 1 月 22 日 : 東京) にて口演した。

\section{引用文献}

1) Grillo HC: Terminal or mural tracheostomy in the anterior mediastinum. $\mathrm{J}$ Thoracic \& Cardiovas Surg, 51: 422-427, 1966.

2) Sisson GA, Straehley CJ, Johnson NE : Mediastinal dissection for recurrent cancer after laryngectomy. Laryngoscope, 72 : 10641077, 1962.

3）村上 泰：縱隔気管孔造設術. JOHNS, 10 : 13331339, 1994

4）篠田雅幸, 高木 厳, 竹市夢二, 他 : 気管浸潤食道 癌に対する有茎広背筋皮弁を用いた縦隔気管瘦形成 術. 手術, 44:1009-1013, 1990.

5）川端一嘉, 鎌田信悦, 高橋久昭: 上縦隔の手術. 耳 鼻と臨床, $38: 712-718,1992$

6) Grillo HC, Mathisen DJ : Cervical exenteration. Ann Thorac Surg 49: 401-409, 1990.

7）村上 泰, 向井 将, 浅岡一之, 他: 前縦隔を経由 する永久気管瘦造設手術。日気食会報，28：300305, 1977. 